\title{
Pengaruh Dosis Pupuk NPK Phonska dan Pupuk Kotoran Sapi Terhadap Pertumbuhan dan Produksi Kacang Hijau (Vigna radiata L.)
}

\author{
Effects of NPK Phonska and Cow Dung Manure Fertilizer Dosages on the Growth and Yield of \\ Mung Bean (Vigna radiata L.)
}

\author{
Johan Riry*, Charles Silahooy, Vilma L. Tanasale, Marlita H. Makaruku \\ Jurusan Budidaya Pertanian, Fakultas Pertanian, Universitas Pattimura, Jl. Ir. M. Putuhena, Kampus Poka, \\ Ambon 97233, Indonesia \\ *E-mail Penulis Korespondensi: riryjohan@gmail.com
}

\begin{abstract}
Mung bean is one of the leguminous plants that is very important to be developed and is a very popular crop for consumption in Indonesia. The use of inorganic fertilizer mix (NPK Phonska) is useful for increasing the production of this crop, but its continuous use without being balanced with soil improvement efforts can lead to negative effects on the soil and crop production. Thus, it is necessary to study the use of combination of inorganic fertilizers (NPK Phonska) with organic cow manure. This study aimed to determine the effects of doses of NPK Phonska fertilizer and cow dung manure on the growth and yield of mung beans. This study used a Randomized Block Design, with two factors. The first factor was dosage of NPK Phonska fertilizer mix, consisting of four levels i.e.: AO (control, without provision), A1 (75 $\mathrm{kg}$ per ha), A2 (150 kg per ha), and A3 (225 kg per ha); and the second factor was composed of three levels, i.e.: KO (control, without provision), K1 (15 ton per ha) and K2 (30 ton per ha). The experiment was done with three replications, so that there were 36 experimental units. The results showed that NPK Phonska fertilizer at a dose of 200 $\mathrm{kg}$ per ha (A3) and manure at a dose of 30 ton per ha (K2) gave the highest yield for all observation variables compared with other treatments, with a yield level of 1.82 tons per ha.
\end{abstract}

Keywords: cow dung, mungbeans, NPK Phonska fertilizer

\section{ABSTRAK}

Kacang hijau merupakan salah satu tanaman leguminoseae yang sangat penting untuk dikembangkan dan merupakan tanaman yang sangat digemari untuk dikomsumsi di Indonesia. Penggunaan pupuk anorganik (NPK Phonska) berguna untuk meningkatkan produksi tanaman ini, namun penggunaannya secara terus menerus tanpa diimbangi upaya perbaikan tanah dapat menimbulkan efek negatif terhadap tanah dan produksi tanaman. Dengan demikian, perlu kajian penggunaan kombinasi pupuk anorganik (NPK Phonska) dengan pupuk organik kotoran sapi. Penelitian ini bertujuan untuk menentukan dosis pupuk NPK Phonska dan kotoran sapi terhadap pertumbuhan dan produksi tanaman kacang hijau. Rancangan yang digunakan dalam penelitian ini adalah Rancangan Acak Kelompok (RAK) 2 faktor yaitu faktor pertama pemberian pupuk NPK Phonska yang terdiri dari empat taraf yaitu A0 (Kontrol, tanpa pemberian), A1 (75 kg per ha), A2 (150 kg per ha), dan A3 (225 kg per ha) serta faktor kedua terdiri dari tiga taraf yaitu K0 (kontrol, tanpa pemberian), K1 (15 ton per ha) dan K2 (30 ton per ha), dengan 3 ulangan sehingga terdapat 36 satuan percobaan. Hasil penelitian menunjukkan bahwa pemberian pupuk NPK Phonska dengan dosis 225 $\mathrm{kg}$ per ha (A3) dan pupuk kotoran sapi dengan dosis 30 ton per ha (K2) memberikan hasil tertinggi untuk semua pengamatan bila dibandingkan dengan perlakuan lainnya, dengan produksi yang dicapai sebesar 1,62 ton per ha.

Kata kunci: kacang hijau, kotoran sapi, pupuk NPK Phonska

\section{PENDAHULUAN}

Salah satu tanaman leguminoseae yang sangat penting untuk dikembangkan di Indonesia adalah kacang hijau. Kacang hijau merupakan tanaman legumoniseae yang sangat digemari untuk dikomsumi oleh masyarakat Indonesia. Kebutuhan akan kacang hijau dari tahun ke tahun semakin meningkat.
Kebutuhan rata-rata kacang hijau di Indonesia dapat mencapai 350.00 ton per tahun, sedangkan produksi yang dicapai hanya sekitar 311.658 ton, (Dirjen Tanaman Pangan. 2012 ), sehingga produksi kacang hijau menurun sehingga tidak dapat memenuhi kebutuhan konsumen.

Penyebab penurunan produksi kacang hijau ini disebabkan oleh kurangnya pengetahuan petani tentang 
teknik budidaya yang tepat pada tanaman kacang hijau khususnya pada tahapan proses pemupukan serta kesulitan petani dalam memperoleh benih yang berkualitas tepat pada waktunya. (Purwono dan Hartono, 2005). Kacang hijau merupakan tanaman multiguna dapat digunakan sebagai bahan pangan, pakan ternak dan pupuk hijau, yang bergizi menyebabkan peningkatan permintaan di pasaran.

Kebutuhan konsumen terhadap kacang hijau yang meningkat tidak sejalan sejalan dengan hasil yang diperoleh pada tanaman kacang hijau, sehingga produksi kacang hijau dalam negeri belum mampu untuk mencukupi kebutuhan konsumen. Produksi yang minimum ini disebabkan oleh berbagai faktor. Salah satu faktor yang sangat mempengaruhi penurunan produksi kacang hijau, yaitu kurangnya pemahaman petani tentang teknik budidaya kacang hijau yang tepat. Rendahnya pengetahuan petani tentang penggunaan pupuk belum optimal menyebabkan produksi tidak optimum.

Pupuk merupakan sumber nutrisi bagi tanaman sehingga dapat digunakan untuk mengatasi berbagai masalah pada tingkat kesuburan dan dapat mensuplai kebutuhan hara bagi tanaman kacang hijau. Ada berbagai jenis pupuk yang beredar di pasaran, akan tetapi pemilihan jenis pupuk yang tepat baik jenisnya, dosisnya dan waktu aplikasinya sangat mempengaruhi pertumbuhan dan produksi tanaman. Berdasarkan penggolongannya ada dua jenis pupuk, yaitu pupuk anorganik dan organik. Pupuk anorganik merupakan pupuk yang merupakan gabungan antara pupuk buatan dan pupuk organik yang dihasilkan melalui proses fermentasi bahan-bahan organik yang berasal dari pupuk hijau, pupuk kotoran sapi, kompos dan organik cair (Hadisuwito, 2012; Sutanto, 2002) sedangkan pupuk organik merupakan pupuk yang berasal dari proses fermentasi bahan organik baik yang berasal dari tanaman ataupun hewan yang dapat dihasilkan dalam bentuk padat ataupun cair. Peningkatan produktivitas kacang hijau diperkirakan dapat diperoleh melalui pemupukan organik dan anorganik. (Kuntyastuti dan Lestari, 2015)

Pupuk anorganik lebih mudah diserap oleh tanaman, namun dalam jangka waktu yang panjang kurang baik bagi sifat fisik, kimia dan biologi tanah. Sedangkan pupuk organik dapat diserap oleh tanaman secara perlahan lahan dalam jangka waktu yang panjang sehingga dapat memperbaiki sifat fisik, kimia dan biologi tanah. Menurut (Sha et al., 2003; Raihana dan Willian 2006, Mondal et al., 2015) proses aplikasi pupuk yang berasal dari hasil penggabungan pupuk organik dan anorganik dapat meningkatkan kadar bahan organik dan unsur hara dalam tanah serta nilai ekonomi $\mathrm{N}$ dalam pola tanam, sehingga produksi biji dan biomasa kacang hijau meningkat. Selain itu, menurut Nasahi, 2010, Sari et al., 2014, aplikasi pupuk kandang yang berasal dari bahan dasar pembuatan kotoran ternak yang langsung diaplikasikan pada lahan pertanian mampu memperbaiki tingkat kesuburan tanah.
Pupuk lengkap atau yang biasanya disebut sebagai Pupuk NPK (Nitrogen phosphate kalium) mengandung tiga unsur hara primer yang utama $(\mathrm{N}, \mathrm{P}$ dan $\mathrm{K}$ ), sehingga tidak perlu digabungkan lagi dengan pupuk lainnya karena haranya sudah tersedia (Sarif, 1985). Menurut Kuntyastuti dan Lestari (2015), telah terjadi peningkatan produksi kacang hijau dengan penggunaan pupuk NPK, bila dibandingkan dengan dengan pemupukan NP, NK, atau PK akan tetapi, perlu adanya penggabungan antara penggunaan pupuk anorganik (NPK Phonska) dengan pupuk organik kotoran sapi, karena pupuk organik kotoran sapi merupakan bahan dasar potensial pembuatan pupuk organik (Budiyanto, 2011; Nurbaetun et al., 2015; Latuamury, 2015).

Pupuk kotoran sapi merupakan hasil fermentasi bahan organik yang sangat bermanfaat dalam meningkatkan kesuburan tanah sehingga memperbaiki pertumbuhan dan produksi tanaman (Lingga dan Marsono, 2013; Arisna et al., 2015; Qibtyah, 2017; Novizan, 2005). Pupuk kotoran sapi sangat bermanfaat dalam memperbaiki sifat fisik, kimia dan biologi tanah, karena mengandung butiran-butiran bahan organik, sehingga lebih mampu dalam mengikat air dalam jumlah yang lebih banyak dan lebih lama, meningkatkan kondisi kehidupan mikroba di dalam tanah. Pupuk kotoran sapi juga merupakan sumber makanan bagi tanaman walaupun dalam jumlah yang sedikit tapi mengandung unsur hara yang lengkap (Sutanto, 2002).

Dalam proses pemupukan ada beberapa hal yang perlu diperhatikan, antara lain tanaman yang diberi pupuk, jenis tanah pada media tanah yang digunakan, jenis pupuk yang digunakan, dosis yang diberikan, waktu pemupukan dan cara pemupukan (Buckman dan Brady, 1982; Jumini et al., 2011) Peningkatan pertumbuhan dan produksi tanaman sangat dipengaruhi oleh penggunaan jenis pupuk yang tepat. Untuk itu perlu dilakukan penelitian pada tanaman kacang hijau guna meningkatkan pertumbuhan dan produksinya, melalui aplikasi dosis pupuk NPK Phonska dan kotoran sapi sehingga dapat memperoleh dosis yang tepat dari kedua jenis pupuk tersebut dan melihat pengaruhnya terhadap pertumbuhan dan produksi tanaman.

Penelitian ini bertujuan untuk menentukan dosis pupuk NPK Phonska dan kotoran sapi terhadap pertumbuhan dan produksi tanaman kacang hijau. Kegunaan penelitian ini adalah sebagai bahan informasi tentang pemanfaatan NPK Phonska dan pupuk kotoran sapi yang tepat dalam pertanaman kacang hijau bagi petani maupun instansi terkait, serta dapat dijadikan sebagai bahan masukan bagi penelitian selanjutnya. Hipotesis yang dipakai pada penelitian adalah dosis pupuk NPK Phonska $225 \mathrm{~kg}$ per ha dan dosis pupuk kotoran sapi 30 ton per ha akan memberikan pengaruh yang terbaik terhadap pertumbuhan dan produksi tanaman kacang hijau (Vigna radiata $\mathrm{L}$.). 


\section{BAHAN DAN METODE}

Penelitian ini dilaksanakan di Desa Neniari, Kecamatan Piru, Kabupaten Seram Bagian Barat, berlangsung dari bulan Maret sampai dengan Juli 2017. Bahan yang digunakan dalam penelitian ini adalah benih kacang hijau varietas Parkit, pupuk NPK Phonska, pupuk kotoran sapi dan insektisida Furadan 3G. Alat yang digunakan meliputi pacul, sekop, parang, sabit, hand sprayer, meteran, timbangan, alat tulis menulis. Penelitian ini menggunakan Rancangan Acak Kelompok (RAK) dengan 2 faktor. Faktor pertama adalah dosis NPK Phonska (A), terdiri dari empat taraf, yaitu: A0 (Kontrol, tanpa pemberian), A1 pemberian 75 $\mathrm{kg}$ per ha setara $45 \mathrm{~g}$ per petak, A2 pemberian $150 \mathrm{~kg}$ per ha setara $90 \mathrm{~g}$ per petak, A3 pemberian $225 \mathrm{~kg}$ per ha setara $135 \mathrm{~g}$ per petak. Faktor kedua adalah dosis pupuk kotoran sapi (K), terdiri dari tiga taraf, yaitu: K0 (kontrol, tanpa pemberian), K1 pemberian 15 ton per ha setara $12 \mathrm{~kg}$ per petak, K2 pemberian 30 ton per ha setara $18 \mathrm{~kg}$ per petak. Terdapat 12 kombinasi perlakuan yang diulang 3 kali sehingga terdapat 36 satuan percobaan.

Penanaman dilakukan secara tugal, kemudian benih ditanam sebanyak 3 butir per lubang tanam, dengan jarak tanam $30 \mathrm{~cm} \times 30 \mathrm{~cm}$. Sebelum ditanam benih direndamkan dengan air yang dicampur dengan insektisida Furadan 3G, yang bertujuan untuk mencegah hama yang terikut dalam benih maupun yang berada di dalam tanah. Pupuk yang digunakan adalah pupuk NPK Phonska dan pupuk kotoran sapi, sesuai perlakuan. Setelah tanaman kacang hijau bertumbuh dilakukan penjarangan dengan meninggalkan 2 tanaman per lubang tanam. Proses pemeliharaan tanaman meliputi: proses penyiraman, penyulaman, penyiangan, pengendalian hama dan penyakit.

Pengamatan dilakukan terhadap tanaman sampel yang ditetapkan secara acak pada setiap satuan percobaan meliputi: tinggi tanaman $(\mathrm{cm})$, jumlah daun (helai), jumlah polong per tanaman, berat kering 1000 biji $(\mathrm{g})$, berat per petak $(\mathrm{g})$, produksi biji kering (ton per ha). Data yang diperoleh dianalisis secara statistik dan jika menunjang perbedaan yang nyata atau sangat nyata maka dilanjutkan dengan uji beda nilai jujur (BNJ) pada taraf 0,05 (Steel and Torrie,1999; Gaspersz, 1992; Sastrosupadi, 2007).

\section{HASIL DAN PEMBAHASAN}

Perlakuan pupuk NPK-Phonska memberikan pengaruh yang nyata pada semua parameter produksi, tetapi pada parameter pertumbuhan menunjukkan pengaruh yang tidak nyata. Pemberian pupuk kotoran sapi memberikan pengaruh yang tidak nyata pada semua variabel yang diamati. Hasil penelitian memperlihatkan bahwa tidak terdapat interaksi antara pemberian pupuk NPK Phonska dan pupuk kotoran sapi (Tabel 1).

Rata-rata perlakuan untuk semua parameter pengamatan disajikan pada Tabel 2 dan Tabel 3 . Berdasarkan Tabel 2 dapat dijelaskan bahwa pada uji lanjut BNJ pemberian pupuk NPK Phonska menunjukkan pengaruh yang berbeda pada semua parameter, walaupun dalam analisis sidik ragam (Tabel 1) menunjukkan pengaruh nyata hanya pada parameter produksi. Pada pemberian pupuk NPK Phonska terlihat adanya perbedaan hasil rata-rata pada variabel-variabel berat 1000 biji, berat per petak dan produksi per ha.

Tabel 1. Hasil analisis ragam penelitian

\begin{tabular}{|c|c|c|c|c|c|c|}
\hline$\frac{\text { Variabel }}{\text { Sumber Keragaman }}$ & $\begin{array}{l}\text { Tinggi } \\
\text { tanaman }\end{array}$ & $\begin{array}{l}\text { Jumlah } \\
\text { daun }\end{array}$ & $\begin{array}{l}\text { Jumlah } \\
\text { polong }\end{array}$ & $\begin{array}{l}\text { Berat } 1000 \\
\text { biji }(\mathrm{g})\end{array}$ & $\begin{array}{l}\text { Berat per } \\
\text { petak }(g)\end{array}$ & $\begin{array}{c}\text { Produksi } \\
\text { per ha } \\
(\mathrm{kg})\end{array}$ \\
\hline Ulangan & ns & ns & ns & ns & $\mathrm{ns}$ & ns \\
\hline Pupuk NPK-Phonska (A) & ns & ns & ns & $*$ & $*$ & $*$ \\
\hline Pupuk kotoran sapi (K) & ns & ns & ns & ns & ns & ns \\
\hline Interaksi A x K & ns & ns & ns & ns & ns & $\mathrm{ns}$ \\
\hline
\end{tabular}

Keterangan: $\mathrm{ns}=$ non signifikan/tidak nyata; $*$ = nyata

Tabel 2. Uji beda rata-rata hasil pengamatan pada perlakuan pupuk NPK phonska

\section{Variabel Pengamatan}

\begin{tabular}{ccccccc} 
Perlakuan & Tinggi & Jumlah daun & $\begin{array}{c}\text { Jumlah } \\
\text { polong }\end{array}$ & $\begin{array}{c}\text { Berat } 1000 \\
\text { biji }(\mathrm{g})\end{array}$ & $\begin{array}{c}\text { Berat per } \\
\text { petak }(\mathrm{kg})\end{array}$ & $\begin{array}{c}\text { Produksi (ton } \\
\text { per ha) }\end{array}$ \\
\cline { 2 - 7 } & $56,62 \mathrm{a}$ & $47,78 \mathrm{a}$ & $28,48 \mathrm{a}$ & $82,42 \mathrm{a}$ & $0,82 \mathrm{a}$ & $0,96 \mathrm{a}$ \\
$\mathrm{A} 0$ & $58,16 \mathrm{a}$ & $52,32 \mathrm{a}$ & $30,64 \mathrm{ab}$ & $86,88 \mathrm{~b}$ & $0,91 \mathrm{a}$ & $1,12 \mathrm{~b}$ \\
A1 & $57,62 \mathrm{a}$ & $50,55 \mathrm{a}$ & $32,12 \mathrm{ab}$ & $118,24 \mathrm{c}$ & $0,93 \mathrm{a}$ & $1,24 \mathrm{~b}$ \\
A2 & $60,76 \mathrm{~b}$ & $54,53 \mathrm{ab}$ & $32,16 \mathrm{~b}$ & $196,74 \mathrm{~d}$ & $0,98 \mathrm{~b}$ & $1,54 \mathrm{c}$ \\
A3 & 2,86 & 4,46 & 4,36 & 7,52 & 0,08 & 0,17 \\
\hline Nilai BNJ & &
\end{tabular}

Keterangan: Angka-angka dalam satu kolom yang diikuti oleh huruf yang sama tidak berbeda nyata menurut uji BNJ 0,05 
Tabel 3. Uji beda rata-rata hasil pengamatan perlakuan pupuk kotoran sapi

Variabel Pengamatan

\begin{tabular}{|c|c|c|c|c|c|c|}
\hline Perlakuan & $\begin{array}{c}\text { Tinggi } \\
\text { Tanaman }\end{array}$ & Jumlah daun & $\begin{array}{l}\text { Jumlah } \\
\text { Polong }\end{array}$ & $\begin{array}{c}\text { Berat } 100 \text { biji } \\
(\mathrm{g})\end{array}$ & $\begin{array}{c}\text { Produksi per } \\
\text { Petak (kg) }\end{array}$ & $\begin{array}{l}\text { Produksi (ton } \\
\text { per ha) }\end{array}$ \\
\hline K0 & $58,66 \mathrm{a}$ & $48,16 \mathrm{a}$ & $28,14 \mathrm{a}$ & $122,62 \mathrm{a}$ & $0,76 \mathrm{a}$ & $1,30 \mathrm{a}$ \\
\hline $\mathrm{K} 1$ & $59,14 \mathrm{a}$ & $50,43 \mathrm{a}$ & $30,22 \mathrm{a}$ & $124,78 \mathrm{a}$ & $0,78 \mathrm{a}$ & $1,36 \mathrm{a}$ \\
\hline $\mathrm{K} 2$ & $62,14 \mathrm{a}$ & $55,26 \mathrm{a}$ & $32,64 \mathrm{a}$ & $126,28 \mathrm{a}$ & $0,82 \mathrm{a}$ & $1,42 \mathrm{a}$ \\
\hline Nilai BNJ & 3,23 & 5,14 & 5,12 & 8,65 & 0,11 & 0.21 \\
\hline
\end{tabular}

Keterangan: Angka-angka dalam satu kolom yang diikuti oleh huruf yang sama tidak berbeda nyata menurut uji BNJ 0,05

Berdasarkan hasil uji beda perlakuan terhadap semua parameter (Tabel 2) terlihat bahwa pada perlakuan pupuk NPK Phonska dosis $75 \mathrm{~kg}$ per ha (A1) setara $45 \mathrm{~g}$ per petak, dosis $150 \mathrm{~kg}$ per ha (A2) setara 90 $\mathrm{g}$ per petak tidak berbeda dengan kontrol untuk variabel tinggi tanaman dan jumlah daun. Untuk jumlah polong, berat 1000 biji, dan produksi per hektar pemberian pupuk $75 \mathrm{~kg}$ per ha memberikan hasil yang berbeda dibandingkan dengan kontrol. Perlakuan A3 (225 kg per ha setara $135 \mathrm{~g}$ per petak) memberikan hasil yang tertinggi untuk semua variabel pengamatan.

Tabel 3 menunjukkan bahwa tidak ada perbedaan antara semua taraf pemupukan kotoran sapi, namun ada sedikit kecenderungan terjadi peningkatan untuk semua variabel pengamatan sejalan dengan peningkatan dosis pupuk kotoran sapi, bahwa dosis pupuk kotoran sapi 30 ton per ha memberikan hasil yang lebih tinggi walaupun secara statistik tidak berbeda.

Pemberian unsur hara pada tanah dilakukan secara langsung dan tidak langsung melalui proses pemupukan, ini dapat berpengaruh dalam mensuplai nutrisi pada tanaman guna meningkatkan proses pertumbuhan dan produksi tanaman kacang hijau. Hara tanaman harus dalam keadaan tersedia untuk memenuhi semua kebutuhan tanaman (Pranta, 2004). Pupuk NPK Phonska mengadung hara makro dalam jumlah yang tersedia. Nitrogen berfungsi sebagai penyusunan asamasam amino, nukleat, nikotin, protein, klorofil, alkaloid. Protein merupakan penyusun utama sel tanaman yang befungsi sebagai bahan penting enzim yang berperan dalam proses metabolime tanaman (Buckman dan Brandy, 1982; Susongko, 2010). Fosfor berfungsi sebagai penyusun fosfat anorganik yang merupakan bagian dari sistem buffer tanaman, nukleo-protein, bagian dari enzim, berperanan dalam sintesis, hidrat arang, lemak, dan protein. Unsur fosfor ini juga sangat penting sebagai sumber energi dalam bebagai aktivitas metabolism, seperti pada proses fotosintesis. Kalium berperan dalam sintesis karbohidrat dan protein serta mengatur aktivitas enzim.

Pertumbuhan dan produksi tanaman sangat ditentukan oleh faktor dalam dan luar tanaman; faktor dalam seperti kualitas benih dan sifat-sifat genetik tanaman, sedangkan faktor luar seperti status hara pada tanah/tingkat kesuburan tanah, iklim (cahaya, curah hujan, angin suhu dan kelembaban) serta kondisi hama dan penyakit (Setyati, 1991). Selain itu menurut
Gardner et al. (1991) dan Susanti et al. (2012), pertumbuhan tanaman dipengaruhi oleh 2 faktor, yaitu faktor genetika dan faktor lingkungan. Faktor lingkungan terdiri atas faktor biotik, seperti hama, penyakit, gulma, mikroorganisme tanah dan faktor abiotik yang meliputi cahaya matahari, kecepatan angin, kelembaban udara, curah hujan dan kesuburan tanah.

Hasil ertinggi diperoleh pada perlakuan pupuk NPK Phonska dengan dosis $225 \mathrm{~kg}$ per ha. Penambahan pupuk NPK Phonska sampai $225 \mathrm{~kg}$ per ha mampu mendukung pertumbuhan tanaman karena menyediakan unsur hara bagi tanaman sehingga tanaman dapat berproduksi dengan baik. Unsur hara $\mathrm{N}$ dan $\mathrm{K}$ lebih berperan dalam pertumbuhan vegetatif, sedangkan proses terbentuknya buah dan biji sangat didukung dengan tersedianya unsur P (Sarief, 1985; Arifin, 2010; Sudarmi, 2013). Tabel 3 menunjukkan bahwa semua hasil pengamatan terhadap semua parameter menunjukkan ada peningkatan pada setiap taraf pupuk yang diberikan. Tabel 3 memperlihatkan bahwa semua data masih bersifat linier dan belum ada kecenderungan kuadratik, hal ini menunjukkan bahwa masih akan terjadi peningkatan produksi bila dosis pupuk dinaikan lebih dari $225 \mathrm{~kg}$ per ha.

Menurut Sarief (1985) dan Sarianti et al. (2015), bahwa unsur hara yang terkandung di dalam pupuk, seperti nitrogen $(\mathrm{N})$ merupakan penyusun protein, klorofil dan enzim-enzim. Pertumbuhan vegetatif tanaman, seperti akar, batang dan daun sangat didukung oleh $\mathrm{N}$ yang merupakan salah satu unsur hara makro (Susongko, 2010; Jumini et al., 2011). Selain itu N juga berfungsi sebagai pendorong utama pertumbuhan vegetatif dan generatif seta pembentukan enzim dan hormon pertumbuhan. Fosfor $(\mathrm{P})$ berfungsi dalam pembelahan sel, perkembangan akar, mempercepat laju pertumbuhan, mempercepat keluarnya bunga, mendorong pembuahan dan pemasakkan buah. Kalium (K) sangat penting dalam proses metabolisme karbohidrat, sintesis asam amino dan protein, sehingga unsur-unsur hara tersebut merupakan unsur utama bagi tanaman dan apabila ketersediaannya cukup di dalam tanah maka pertumbuhan tanaman akan meningkat. $\mathrm{K}$ juga berfungsi mengaktifkan enzim-enzim yang berperan dalam metabolisme dan biosintesis. Menurut Pranata (2004) dan Suwahyono (2017), unsur hara yang terkandung di dalam pupuk NPK Phonska, seperti unsur $\mathrm{N}$ yang merupakan penyusun klorofil, meningkatkan 
pertumbuhan daun dan batang, meningkatkan perkembangbiakan mikroorganisme dalam tanah; $\mathrm{P}$ berfungsi dalam menyimpan dan pemindahan energi, dapat merangsang pertumbuhan akar, terbentuknya bunga serta masak bunga, biji dan gabah; sedangkan unsur K berperan dalam berbagai proses di antaranya pembentukan protein dan karbohidrat, mengeraskan bagian kayu dari tanaman, dan meningkatkan kualitas biji atau buah.

Kesuburan tanah yang meningkat dari penggunaan pupuk NPK Phonska dan pupuk kandang akan meningkatkan pertumbuhan dan produksi tanaman, sehingga meningkatkan pula bobot/berat tanaman (Tabel 2 dan 3). Hal ini terlihat pada analisis ragam masing-masing perlakuan yang diberikan pupuk NPK Phonska, yang menunjukkan bahwa pada perlakuan A3 diperoleh bobot berat 1000 biji tanaman yang lebih tinggi, yaitu 196,74 gram. Ini dikarenakan terjadinya perbanyakan jaringan tanaman dalam proses partumbuhannya yang berlangsung dengan cepat. Sebagaimana Setyati (1991), pertumbuhan tanaman adalah penambahan ukuran dan biomassa yang tidak dapat balik, yang didorong oleh tersedianya unsur-unsur hara yang mencukupi.

Fotosintesis dapat berjalan dengan baik apabila tanaman memiliki pertumbuhan baik yang dicirikan dengan batang, cabang dan daun yang tumbuh subur. Apabila fotosintesis berjalan dengan baik

maka fotosintat yang dihasilkan lebih banyak, sehingga dapat digunakan untuk pertumbuhan tinggi tanaman dan perkembangan pada fase generatif. Terbentuknya bunga dan buah perlu didukung oleh hasil fotosintat, sehingga produksi yang dihasilkan baik, yang ditandai dengan peningkatan jumlah, ukuran dan berat biji. Sarief (1985) mengemukakan bahwa tanaman menyerap air dan unsur hara di dalam tanah untuk mempengaruhi laju fotosintesis, sehingga jumlah fotosintat yang dihasilkan lebih banyak yang akan dimaanfaatkan untuk pembentukan bunga.

\section{KESIMPULAN}

Kesimpulan yang dapat diambil pada penelitian ini adalah: 1) Tidak terdapat pengaruh interaksi antara kedua jenis pupuk yang digunakan; pupuk NPK Phonska dan pupuk kandang berpengaruh secara mandiri terhadap semua variabel pengamatan; 2) Pupuk kotoran sapi tidak memberikan pengaruh yang nyata dan tidak ada perbedaan di antara semua taraf dosis yang diberikan; dan 3) Perlakuan pupuk NPK Phonska dengan dosis $200 \mathrm{~kg}$ per ha memberikan pertumbuhan dan produksi yang terbaik.

\section{UCAPAN TERIMA KASIH}

Terima kasih kepada semua pihak yang sudah membantu dalam penelitian ini, khususnya Dinas Pertanian dan Peternakan Kabupaten Seram Bagian Barat, Provinsi Maluku.

\section{DAFTAR PUSTAKA}

Arifin, M. 2010. Kajian sifat fisika tanah dan berbagai penggunaan lahan dalam hubungannya dengan pendugaan erosi tanah. Jurnal Pertanian Mapeta 12(2):72-144.

Arisna P.J., Armaini, dan E. Ariani. 2016. Pengaruh pupuk kandang sapi dan jarak tanam terhadap pertumbuhan serta hasil jagung semi (baby corn) dan kacang hijau (Vigna radiata L.) pada pola tumpangsari. Jurnal Online Mahasiswa Faperta 4(1): 18-23.

Buckman, H.O. dan N.C. Brady. 1982. Ilmu Tanah. Terjemahan: Soegiman. Bhratara Karya Aksara. Jakarta.

Budiyanto, M.A.K. 2011. Tipologi pendayagunaan kotoran sapi dalam upaya mendukung pertanian organik di Desa Sumbersari Kecamatan Poncokusuma Kabupaten Malang. Jurnal Gamma 7(1): 42-49.

Dirjen Tanaman Pangan. 2012. Pedoman Pelaksanaan Program Peningkatan Produksi, Produktivitas dan Mutu Tanaman Pangan Untuk Mencapai Swasembada dan Swasembada Berkelanjutan. Dirjen Tanaman Pangan, Kementerian Pertanian, Jakarta.

Gardner, F.P., R.B. Pearce, dan L.R. Mitchell. 1991. Fisiologi Tanaman Budidaya. Penerjemah: H. Susilo, UI Press, Jakarta.

Gaspersz, V. 1999. Teknik Analisis Dalam Penelitian Percobaan. Tarsito, Bandung.

Hadisuwito, S. 2012. Membuat Pupuk Organik Cair. PT. Agromedia Pustaka. Depok.

Jumini, J., Nurhayati, dan Murzani. 2011. Efek kombinasi dosis pupuk $\mathrm{N}, \mathrm{P}, \mathrm{K}$ dan cara pemupukan terhadap pertumbuhan dan hasil jagung manis Banda Aceh. Jurnal Floratek 6: 165-170.

Kuntyastuti, H. dan S.A.D. Lestari. 2015. Pengaruh interaksi antara dosis pupuk dan populasi tanaman terhadap pertumbuhan dan hasil kacang hijau pada lahan kering beriklim kering. Jurnal Penelitian Pertanian Tanaman Pangan 35(3): 239-249. DOI: $\quad 10.21082 /$ jpptp.v35n3. 2016.p\%25p.

Latuamury N., 2015. Pengaruh tiga jenis pupuk kandang terhadap pertumbuhan dan produksi tanaman kacang hijau (Vigna Radiata L.). Jurnal Agroforestri 10: 109-116.

Lingga, P. dan Marsono. 2013. Petunjuk Penggunaan Pupuk. Penebar Swadaya. Jakarta.

Mondal, N.K., J.K. Datta, and A. Banerjee. 2015. Integrated effects of reduction dose of nitrogen fertilizer and mode of biofertilizer application on soil health under mungbean cropping system. Commun. Plant Sci. 5(1-2): 15-22.

Nasahi, C. 2010. Peran Mikrobia Dalam Pertanian Organik. Jurusan Hama dan Penyakit Tumbuhan Fakultas Pertanian Padjajaran, Bandung. 
Novizan. 2005. Petunjuk Pemupukan Yang Efektif. PT AgroMedia Pustaka. Jakarta.

Nurbaetun, I., M. Surahman dan A. Ernawati. 2015. Pengaruh dosis pupuk NPK dan jarak tanam terhadap pertumbuhan dan produksi kacang koro pedang (Canavalia ensoformis). Agrohorti 5(1): 17-26. DOI: 10.29244/agrob. v5i1.15885.

Pranata, A.S. 2004. Pupuk Organik Cair, Aplikasi dan Manfaatnya. PT. Agromedia Pustaka, Jakarta.

Purwono dan R. Hartono, 2005. Teknik Budidaya Kacang Hijau. Penebar Swadaya. Depok.

Qibtyah, M. 2017. Pengaruh jarak tanam dan frekuensi penyemprotan pupuk cair terhadap pertumbuhan dan produksi kacang hijau (Phaseolus Radiatus L.). Saintist Jurnal Ilmu-ilmu Eksakta 9(1): 83106.

Raihana, Y. dan E. William. 2006. Pemberian mulsa terhadap tujuh varietas kacang hijau dan keharaan tanah di lahan lebak tengahan. Buletin Agronomi 34(3): 148-152.

Sari, D.K., Y. Hasanah dan T. Simanungkalit. 2014. Respons pertumbuhan dan produksi beberapa varietas kedelai (Glycine max L. (Merill)) dengan pemberian pupuk organik cair. Agroekoteknologi 2: 653-661.

Sarianti, N., Gusmeizal, dan R. Aziz. 2017. Pengaruh pemberian pupuk kandang sapi dan super bokasi Aos Amino terhadap pertumbuhan dan produksi kacang hijau (Vigna radiata L.). Agrotekna, Jurnal Agroteknologi dan Ilmu Pertanian (2): 144-159. DOI: 10.31289 /agr. v1i2.1131

Sarif, E.S. 1985. Kesuburan dan Pemupukan Tanah Pertanian. Penerbit Pustaka Buana, Bandung.
Sastrosupadi, A. 2007. Rancangan Percobaan Praktis Bidang Pertanian. Kanisius. Yogyakarta.

Setyati H.S., 1979. Pengantar Agronomi. Penerbit Gramedia, Jakarta.

Shah, Z., S.H. Shah, M.B. Peoples, G.D. Schwenke and D.F. Herridge. 2003. Crop residue and fertiliser $\mathrm{N}$ effects on nitrogen fixation and yields of legume-cereal rotations and soil organic fertility. Field Crops Research 83:1-11. DOI: 10.1016/S0378-4290(03)00005-4.

Steel, R. G. D., dan J. H. Torrie. 1991. Prinsip dan Prosedur Statistika. PT. Gramedia Utama. Jakarta.

Sudarmi, R. Nugraheni, S.N. Catur Rini, H. Yos Wahyu dan A. Setyarini. 2013. Kajian dosis pupuk NPK terhadap hasil dan analisis usaha tani cabe rawit Rama (Capsicum frutensence). Jurnal Widyatama 22(1): 1-9.

Susanti, E.D., Purbajanti, dan Sutarno. 2012. Pertumbuhan hijauan kacang pintoi (Arachis pintoi) pada berbagai panjang stek dosis pupuk organik cair periode pemotongan kedua. Animal Agricultural Journal 1(1): 721-731.

Susongko J., 2010. Pengaruh macam Pupuk NPK dan Macam Varietas terhadap Pertumbuhan dan Hasil Tanaman Terong Ungu (Solanum melongena L.) Ringkasan Skripsi Fakultas Pertanian Univesitas Sebelas Maret. Surakarta.

Sutanto, R. 2002. Pertanian Organik. Menuju Pertanian Alternatif dan Berkelanjutan. Kanisius, Yogyakarta.

Suwahyono, U. 2017. Panduan Penggunaan Pupuk Organik. Penebar Swadaya. Jakarta. 